Available online at: http://ejournal-balitbang.kkp.go.id/index.php/iaj

\title{
THE EFFECTS OF WEANING TIME ON THE GROWTH AND SURVIVAL OF MUD CRAB (Scylla olivacea)
}

\author{
Haryati*\# , Yushinta Fujaya*), and Early Septiningsih $^{* *}$ \\ *) Faculty of Marine Scinces and Fisheries, Hasanuddin University \\ Jl. Perintis Kemerdekaan Km. 10, Tamalanrea Indah, Tamalanrea, Kota Makassar, Sulawesi Selatan 90245 \\ *) Research Institute for Coastal Aquaculture and Fisheries Extension \\ Jl. Makmur Daeng Sitakka No. 129, Raya, Turikale, Kabupaten Maros, Sulawesi Selatan 90512
}

(Received 7 December 2017; Final revised 8 August 2018; Accepted 8 August 2018)

\begin{abstract}
Live foods such as rotifers and Artemia are commonly used as foods in larval rearing of mud crab (S. olivacea). However, the continuous availability and nutritional consistency of live foods are difficult to control. Thus, the development of artificial diets to partially or fully replaced live foods is needed to overcome the limitations of live foods. The purpose of this research was to determine the best stage at which mud crab larvae can be weaned from live foods to artificial diets. The research experiment consisted of: treatment-1, the larvae were fed with live foods from zoea-1 to megalopa stages as the control treatment; treatment-2, the larvae were fed with artificial diet from zoea- 2 to megalopa stages; and treatment-3, the larvae were fed with artificial diet from zoea-3 to megalopa stages. In treatment-4, artificial diet was given from zoea-4 to megalopa stages. The growth and survival rate of larvae in treatment-1, 3, and 4 were not significantly different $(P>0.05)$ but significantly different with treatment-2. Based on the present results, this study suggests that artificial diet can be given to mud crab larvae ( $\mathrm{S}$. olivacea) from the third zoea stage.
\end{abstract}

\section{KEYWORDS: artificial diet; larvae; live foods; S. olivacea; weaning period}

\section{INTRODUCTION}

The major constraint in mud crab farming is the limited supply of seed. Currently, the seeds of mud crab were mostly collected from wild catches where the availability seasonally fluctuates (Serrano \& Traifalgar, 2012). This has led to the widespread seedsstock shortage and over exploitation of the species and the farming activities have been classified as not environmentally friendly. Thus, the development of more effective hatchery techniques and reliable production of mud crab juveniles are needed to ensure the sustainability of mud crab aquaculture.

Feed is one of the factors that determine the success of an aquatic organism larval rearing in a hatchery. Currently, most hatcheries rely on live foods such as rotifers (Brachionus plicatilis) and Artemia salina nauplii. However, live foods are deemed not practical as

\footnotetext{
\# Correspondence: Faculty of Marine Scinces and Fisheries, Hasanuddin University. Jl. Perintis Kemerdekaan Km. 10, Tamalanrea Indah, Tamalanrea, Kota Makassar, Sulawesi Selatan 90245, Indonesia

Phone: + 62411586025

E-mail: haryati_fikpunhas@yahoo.com
}

well as economically in efficient because live foods production may account $50-75 \%$ of the total cost of aquaculture hatcheries (Dainteath \& Quin, 1991). Nutritional profile of live foods is not always consistent which depends on the source, age, and cultivation techniques. Live foods also lack certain nutritional components essential for normal growth of marine larvae. Live foods can also be a vector of pathogens in larval rearing. The production of live foods in hatcheries need specialized work force and requires specific equipment and facilities (Holme, 2008). In large-scale hatchery operations, the use of live food needs to be limited periodically and replaced with artificial diets where the nutritional composition can be tailored to the needs of the larvae.

Artificial diets in the form of micro diet ensure the availability and quality of the feed. The feed can also be formulated according to the requirements of larvae. However, several studies had found that the growth performance and survival rates of mud crab larvae fed with artificial diets were not as good as those fed with live foods (Holme, 2008). The resulting poor growth was likely due to the incomplete development of the digestive organs in the early lar- 
val stage which affects the availability of digestive enzymes. The results of Jantrarotai et al. (2005) study on S. olivacea revealed that, based on histological assessment, the structure of the species' digestive organs had completely developed. Pavasovic et al. (2004) suggested that a successful mud crab hatchery technology requires a comprehensive understanding of the digestion process in the larvae. Such knowledge is not only very important in understanding the physiology of nutrition but also in determining the larval stadia where artificial diets can be applied.

Increased activity of digestion enzymes in larvae can be used as an indicator when artificial diets can be used. Gawlicka et al. (2000) suggested a similar finding that the activity of digestive enzymes is a good indicator to determine the capacity ofthe digestion system in an animal. A significant increase in enzyme activity could mean that, physiologically, larvae are ready to process feed from outside (Gawlicka et al., 2000). For example, the highest increase of trypsin, lipase, and amylase enzymes in S. olivacea larvae occurred at stadia zoea-3 (Haryati et al., 2014). Serrano \& Traifalgar (2012) also found a similar pattern on S. Serrata where the increased activities of trypsin, amylase, and a LAP (Leucine Amino Peptidases) on S. serrata were observed at zoea-3 stage. The objective of this research was to determine the weaning period of S. olivacea larvae from live food to artificial diets.

\section{MATERIALS AND METHODS}

\section{Source of Larvae}

The source mud crab larvae used in this study came from the hatched eggs of mud crab broodstock. The broodstocks were fed daily with squid and trash fish as much as $15 \%$ of their biomass with feeding frequency twice a day at 06.00 and 18.00 .

The larvae were reared in seawater with a salinity of 32-34 ppt filtered through a sand filter, then disinfected using chlorine $40 \mathrm{mg} / \mathrm{L}$, for approximately 12 hours with strong aeration. The seawater was then neutralized using $20 \mathrm{mg} / \mathrm{L}$ thiosulfate and allowed to stand still for 1-2 hours.

Containers used for larval rearing were black plastic buckets of 25 liters in volume. Each container was filled with 20 liters of the sterilized seawater and stocked with the larvae at a density of 50 individuals $\mathrm{L}^{-1}$.

The experiment was arranged in a completely randomized design with four treatments and three replicates (Table 1 ).
The live foods used in these experiments were Brachionus and Artemia nauplius, while the artificial diets was a commercial feed. From zoea-1 to 3 stages, the larvae were fed with Brachionus with a density of 30 individuals $\mathrm{mL}^{-1}$. From zoea-3 to megalopa stages, the larvae were fed with Brachionus with an addition of Artemia nauplii at a density of 5 individuals $\mathrm{mL}^{-1}$. The feeding trial was done twice daily at 07:00 and 22:00. From zoea-1 to zoea-3, the artificial diet was given as much as $5.0 \mathrm{mg} \mathrm{L}^{-1}$ daily and as much as 10 $\mathrm{mg} \mathrm{L}^{-1}$ from zoea-3 to megalopa stages. The artificial feed was given six times daily, at 06.00, 09.00, 12.00, $21.00,15.00,18.00$, and 21.00 .

\section{Parameters}

The experiment was terminated when all zoea- 5 stage had molted to megalopa stage. The parameters measured in this study were growth, survival rate and nutritional value of the artificial diet. Mud crab larvae growth was measured by length and width of the carapace and the specific growth rate. The measurements were carried out at zoea-1 and megalopa stadia using an ocular micrometer and observed under a light microscope. The growth of length $(\boldsymbol{\Delta} L)$ and width carapace ( $\mathbf{\Delta} \mathrm{CW}$ ) were calculated using the following formula:

$$
\Delta \mathrm{L}=\mathrm{L}_{\mathrm{t}}-\mathrm{L}_{0}
$$

where:

$\begin{aligned} \overrightarrow{\Delta L} & =\text { growth of carapace length }(\mathrm{mm}) \\ \overline{\mathrm{L}_{\mathrm{t}}} & =\text { length of carapace at megalopa stage }(\mathrm{mm}) \\ \mathrm{L}_{0} & =\text { length of carapace at zoea-1 stage }(\mathrm{mm})\end{aligned}$

$$
\Delta \mathrm{CW}=\overline{\mathrm{CW}_{\mathrm{t}}}-\overline{\mathrm{CW}_{\mathrm{o}}}
$$

where:

$\mathrm{pCW}=$ growth carapace width $(\mathrm{mm})$

$\mathrm{CW}_{\mathrm{t}}=$ carapace width at megalopae stage $(\mathrm{mm})$

$\mathrm{CW}_{0}=$ carapace width at zoea-1 stage $(\mathrm{mm})$

The specific growth rate (SGR) was calculated according to the following formula:

$$
\operatorname{SGR}(\%)=\frac{\ln W_{f}-\ln W_{i}}{T} \times 100 \%
$$

where:

$W_{f}=$ the natural logarithm of the final weight

$\mathrm{W}_{i}^{\dagger}=$ the natural logarithm of the initial weight

$\mathrm{T}=$ time (days)

The survival rate (SR) was calculated when the larvae had reached the megalopae stage by using the following formula:

SR $(\%)=\frac{\text { The number of larvae at megalo pastage }}{\text { The number of larvae at zoea 1stage }} \times 100 \%$ 
Table 1. Arrangement of treatments based on larval development stages

\begin{tabular}{|c|c|c|c|c|c|}
\hline \multirow{2}{*}{$\begin{array}{l}\text { Zoea started } \\
\text { weaning }\end{array}$} & \multicolumn{5}{|c|}{ Larva stages } \\
\hline & Zoea-2 & Zoea-3 & Zoea-4 & Zoea-5 & Megalopae \\
\hline & \multicolumn{5}{|c|}{ Live foods } \\
\hline Control & Overlap & \multicolumn{4}{|c|}{ Artificial diets } \\
\hline Zoea-2 & Livefoods Overlap & \multicolumn{4}{|c|}{ Artificial diets } \\
\hline & Live foods & Overlap & & Artificial diet & \\
\hline
\end{tabular}

The nutritional value of the feed was evaluated based on the results of the proximate analysis, amino acid, and fatty acid composition. Water quality parameters such as temperature, salinity, and $\mathrm{pH}$ were recorded daily.

\section{Statistical Analysis}

To evaluate the effect of the treatments on growth and survival rate, the data were analyzed using analysis of variance (ANOVA). If there were significant differences among the treatments, Turkey's W-test (Steel \& Torrie, 1991) was used to determine the treatments that produced the best response. The quality of the feed was evaluated descriptively by comparing the nutritional value of the artificial diet with the larvae requirements.

\section{RESULTS AND DISCUSSION}

Results of the analysis of variance showed that the differences in the weaning of live foods with artificial diet were significantly affect $(P<0.05)$ on width and length carapace growth as well as the individual specific growth rate of mud crab larvae from zoea-1 to megalopae stages. The larvae fed with artificial diet started from zoea-3 to zoea-4 had insignificantly different $(P>0.05)$ of growth rates compared with the larvae fed only with live foods started from zoea1 to megalopae. However, the former had higher growth rates which were significantly different $(P<0.05)$ compared with the larvae fed with artificial diets started at zoea-2.

The average survival rate of mud crab larvae from zoea-1 to megalopae stages is presented in Table 3.

Analysis of variance showed that the difference in the starting stage of the weaning of live foods to artificial diet significantly affects $(P<0.05)$ the survival rate of larvae from zoea-1 to megalopae. The larvae fed with artificial diet from zoea-3 to zoea-4 had no significant difference $(P>0.05)$ of survival rates compared with the larvae fed only with live foods started from zoea-1 to megalopae. Similar to the

Table 2. Average growth in length and width carapace $(\mathrm{mm})$ and the specific growth rate $(\%$ of $S$. olivacea from zoea-1 to megalopae stages

\begin{tabular}{lccc}
\hline \multirow{2}{*}{$\begin{array}{c}\text { Replacement of live foods } \\
\text { with artificial diets }\end{array}$} & \multicolumn{2}{c}{ Growth of carapace $(\mathrm{mm})$} & \multirow{2}{*}{$\begin{array}{c}\text { Individual specific } \\
\text { growth rate }(\%)\end{array}$} \\
\cline { 2 - 3 } Control & $3.13 \pm 0.482^{\mathrm{a}}$ & $1.18 \pm 0.146^{\mathrm{a}}$ & $0.0246 \pm 0.0021^{\mathrm{a}}$ \\
Zoea-2 & $2.83 \pm 0.108^{\mathrm{b}}$ & $1.04 \pm 0.040^{\mathrm{b}}$ & $0.0209 \pm 0.0013^{\mathrm{b}}$ \\
Zoea-3 & $3.03 \pm 0.107^{\mathrm{a}}$ & $1.19 \pm 0.020^{\mathrm{a}}$ & $0.0249 \pm 0.0021^{\mathrm{a}}$ \\
Zoea-4 & $3.15 \pm 0.072^{\mathrm{a}}$ & $1.20 \pm 0.021^{\mathrm{a}}$ & $0.0264 \pm 0.0015^{\mathrm{a}}$ \\
\hline
\end{tabular}

Description: control: larvae fed with live foods from zoea 1 to megalopa stages; the same letter within the same column indicates no significant difference in the level of $5 \%$ 
Table 3. The average survival rate (\%) of mud crab (S. olivacea) Iarvae from zoea-1 to megalopae stages

\begin{tabular}{lc}
\hline $\begin{array}{c}\text { Replacement of live foods } \\
\text { with artificial diets }\end{array}$ & $\begin{array}{c}\text { Survival rate } \\
\text { (\%) }\end{array}$ \\
\hline Control & $35.57 \pm 7.01^{\mathrm{a}}$ \\
Zoea-2 & $7.77 \pm 1.37^{\mathrm{b}}$ \\
Zoea-3 & $37.80 \pm 4.91^{\mathrm{a}}$ \\
Zoea-4 & $47.10 \pm 1.84^{\mathrm{a}}$ \\
\hline
\end{tabular}

Description: control: larvae fed with live foods from zoea-1 to megalopae; the same letter indicates no significant difference in the level $5 \%$

growth rates, the survival rates of the former were significantly different $(P<0.05)$ than that of the larvae fed with artificial diets started at zoea-2. The average survival rate of mud crab larvae fed with the artificial diet started at zoea-2 stage was only $7.77 \%$ The larvae fed with the artificial diet started from zoea-3 and zoea-4 and only fed with live foods had much higher survival rates of $37.80 \% 47.10 \%$ and $35.57 \%$ respectively.

The relatively low growth and survival rates of $\mathrm{S}$. olivacea larvae fed with the artificial diet starting at zoea-2 stage was probably caused by the inability of the larvae to digest artificial diets at this stage. This means that less energy and material are available to support the growth and survival of the larvae. Haryati et al. (2015) study showed that the activity of trypsin, á amylase, and lipase enzymes in larvae fed with the artificial diet from zoea-2 which were lower and significantly different compared to the larvae fed only with live foods from zoea-1 to megalopae and larvae fed artificial diets from zoea- 3 and 4 stages. The study findings of Serrano \& Traifalgar (2012) on S. serrata also showed a similar pattern where the increased activity of trypsin, amylase, and $\alpha$ LAP (Leucine Amino Peptidases) were high in zoea-3 larvae. Holme et al. (2006) also found that zoea-3 larvae when fed a diet composed of 50\%MBD and 50\%live Artemia have higher survival and better growth development to reach the next stage (zoea-4) compared to those fed $100 \%$ live Artemia. They argued that the MBD contained nutrient (s) that were beneficial for zoea survival and development, which might be either lacking or available at a limited level in live Artemia. Other studies on fish and penaeid shrimp species also found similar results where formulated diet particles fed in conjunction with live food organisms (termed 'co-feeding') to early larval stages generally supported better survival and growth (Holme, 2008). This can probably be explained by the reduced digestive capabilities in the early larval stages when digestion is heavily reliant on enzymes obtained from live foods.

The results of the proximate analysis are presented in Table 4. The protein, carbohydrates (NFE), and lipid ranged from $44.53 \%$ to $58.58 \% 22.43 \%$ to $29.65 \%$ and $6.15 \%$ to $11.86 \%$ respectively.

The essential amino acid composition was presented in Table 5. The levels of eight amino acids were higher in Brachionus than those in nauplius Artemia and artificial diet. Only one essential amino acid methionine, in Brachionus was lower than that in the nauplius Artemia or in artificial diet. However, the deficiency of this amino acid can be replaced by amino acid cysteine which is a non-essential amino acid. Amino acids threonine, lysine, and histidine in Artemia nauplius were lower than in Brachionus and artificial diets. Arginine amino acid level was higher in Artemia than in Brachionus and artificial diets.

The differences in the growth and survival rate of larvae in this study were suspected to be caused by the nutritional value of feed and the ability of larvae to digest feed. Feed protein content ranged from $44.53 \%$ to $58.58 \%$ According to Genodepa et al. (2004), protein requirement of $S$. serrata at megalopae stage was $79.4 \%$ whereas according to Catacutan (2002), protein requirement of S.serrata juveniles ranged from $34.2 \%$ to $51.8 \%$ Based on the protein content, the feed used have a good quality.

The carbohydrate content (NFE) ranged from $22.43 \%$ to $29.65 \%$ The dietary requirement and utilization of carbohydrates by mud crabs are largely unknown. However, one study by Catacutan et al. (2003) found that $\mathrm{S}$. serrata larvae were able to digest a wide range of carbohydrates. The fat content ranged from $6.15 \%$ to $11.86 \%$ 
Table 4. Value of proximate analysis of feed (\%dry weight)

\begin{tabular}{lcccc}
\hline \multirow{2}{*}{ Composition } & \multirow{2}{*}{ Brachionus } & \multirow{2}{*}{$\begin{array}{c}\text { Artemia } \\
\text { nauplii }\end{array}$} & \multicolumn{2}{c}{ Artificial } \\
\cline { 4 - 5 } & & & Diets-1 & Diets-2 \\
\hline Protein & 54.23 & 58.58 & 45.69 & 44.53 \\
Lipid & 11.86 & 6.15 & 9.01 & 9.37 \\
Fiber & 6.64 & 7.72 & 2.13 & 1.43 \\
NFE & 26.17 & 22.43 & 29.16 & 29.65 \\
Ash & 1.01 & 5.12 & 13.99 & 14.80 \\
\hline
\end{tabular}

Amino acids arginine, histidine, isoleucine, leucine, lysine, methionine, phenylalanine, threonine, tryptophan, and valine are essential in the crustacean diet. Tyrosine and cystine might serve as semi-essential amino acids as their presence in the diet reduces the requirement of phenylalanine and methionine, respectively (Guillaume, 1997). Based on the amino acids composition, threonine, lysine, and histidine in Artemia nauplius were lower than that of Brachionus and artificial diets. The level of the amino acid methionine in Brachionus was lower than that of nauplius Artemia and artificial diets and its role can be replaced by amino acid cystine. Amino acid requirements are qualitatively varied among life stages and very little research has been done to determine amino acid requirements in the development of crustacean larvae (Bengston, 1993).

The fatty acid composition in Brachionus, Artemia nauplius, and artificial diet is presented in Table 6.

Eicosapentaenoic fatty acid (EPA) in Brachionus, Artemia nauplius, and artificial diets were relatively high. Fatty acid DHA was detected in rotifers but its level was diminutive compared to artificial diets. Fatty acid DHA was not detected in Artemia nauplius. Takeuchi (2000) suggested that n-3 HUFA especially EPA and DHA are the essential ingredients for the larvae to survive and support the growth of the carapace. Studies have shown that S. serrata needed the enzyme for de novo synthesis of long chained unsaturated fatty acids (HUFA) (Sheen \& Wu, 1999). The deficiency of n-3 HUFA eicosapentaenoic acid (EPA) and doxosahexaenoic acid (DHA) has been identified as cause of low survival, longer intermolt period, and narrower carapace width (Suprayudi et al., 2004a). The results of a research by Suprayudi et al. (2004b) showed that rotifers enriched with Nannochloropsis had EPA levels ranged from 0.94 to $1.46 \%$ and very low DHA. In this study, EPA level in Artemia ranged from 0.27 to $0.39 \%$ and DHA was untraceable. Based on the content of EPA and DHA, artificial diets quality were relatively the same with in both Brachionus and Artemia.

The water temperature measured during the experiment ranged between $24^{\circ} \mathrm{C}-30^{\circ} \mathrm{C}$. Mardjono et al.

Table 5. Amino acid composition of Brachionus, Artemia nauplii, and artificial diets (\%crude protein)

\begin{tabular}{lcccc}
\hline \multirow{2}{*}{ Amino acid } & \multirow{2}{*}{ Brachionus* } & \multirow{2}{*}{$\begin{array}{l}\text { Artemia } \\
\text { nauplii* }\end{array}$} & \multicolumn{2}{c}{ Artificial } \\
\cline { 4 - 5 } & & & Diets-1** & Diets-2** \\
\hline Phenyllanine & 2.67 & 1.61 & 1.82 & 1.64 \\
Leusine & 4.18 & 2.83 & 2.91 & 2.63 \\
Isoleusine & 2.33 & 1.79 & 1.65 & 1.47 \\
Metionine & 0.54 & 0.82 & 0.78 & 0.73 \\
Valine & 2.88 & 1.91 & 1.98 & 1.77 \\
Threonine & 2.19 & 0.85 & 1.76 & 1.67 \\
Arginine & 3.15 & 4.45 & 2.81 & 2.53 \\
Histidine & 1.10 & 0.36 & 0.90 & 0.78 \\
Lisine & 4.67 & 1.24 & 2.19 & 1.85 \\
Triptofan & Nd & Nd & Nd & Nd \\
\hline Description: & nd= not detected; $*=$ Haryati (2002); **= analysis result in the \\
& Integrated Laboratory Bogor Agriculture Institute
\end{tabular}


Table 6. Fatty acid composition in Brachionus, Artemia nauplius, and artificial diet (\%lipid)

\begin{tabular}{lccccc}
\hline \multirow{2}{*}{ Fatty acid } & Carbon & Brachionus* & $\begin{array}{c}\text { Artemia } \\
\text { nauplii* }\end{array}$ & & \multicolumn{2}{c}{ Artificial } \\
\cline { 5 - 6 } & & & & Diets 1** & Diets 2** \\
\hline Miristic & $\mathrm{C} 14: 0$ & 2.26 & 1.70 & 3.34 & 3.04 \\
Pentadeconic & $\mathrm{C} 15: 0$ & 0.12 & - & 0.33 & 0.28 \\
Palmitic & $\mathrm{C} 16: 0$ & 9.38 & 12.20 & 14.57 & 12.40 \\
Stearic & $\mathrm{C} 18: 0$ & 1.96 & 2.60 & 3.23 & 2.81 \\
Oleic & $\mathrm{C} 18: 1$ & 2.69 & 30.7 & 14.80 & 12.53 \\
Linoleic & $\mathrm{C} 18: 2 \mathrm{n} 6$ & 1.52 & 9.30 & 8.24 & 8.71 \\
Linolenic & $\mathrm{C} 18: 3 \mathrm{n3}$ & 0.40 & 3.30 & 0.05 & 0.07 \\
Arachidonic (ARA) & $\mathrm{C} 20: 4 \mathrm{n} 6$ & 1.40 & 4.60 & 0.241 & 0.39 \\
Eicosapentaenoic (EPA) & $\mathrm{C} 20: 5 \mathrm{n} 3$ & 4.39 & 6.50 & 3.76 & 4.08 \\
Docosahexaenoic (DHA) & $\mathrm{C} 22: 6 \mathrm{n} 3$ & 0.89 & - & 1.72 & 4.81 \\
\hline
\end{tabular}

Description: * Haryati (2002); **= analysis results in Integrated Laboratory Bogor Agriculture Institute

(1994) suggested that the optimum temperature in larval rearing of mud crab ranges from $24^{\circ} \mathrm{C}$ to $31^{\circ} \mathrm{C}$. The salinity of the media during the study was $30 \mathrm{ppt}$ which was well within the optimum salinity range suggested by Mardjono et al. (1994) of 30-35 ppt. The $\mathrm{pH}$ level for all treatments during the study was maintained at 7.5-8.0. According to Shelley et al. (2011) mud crabs should be maintained in media with a $\mathrm{pH}$ range of 7.5-8.5

\section{CONCLUSION}

The present study suggested that weaning in larval rearing of $\mathrm{S}$. olivacea can be done after zoea stage-3.

\section{ACKNOWLEDGEMENTS}

The authors wish to thank the Hasanuddin University that has funded this research through the Research Fund BOPTN 2014.

\section{REFERENCES}

Bengston, D.A. (1993). A comprehensive program for the evaluation of artificial diets. Journal of the World Aquaculture Society, 24, 285-293.

Catacutan, M.R. (2002). Growth and body composition of juvenile mud crab, Scylla serrata, fed different dietary protein and lipid levels and protein to energy ratios. Aquaculture, 208, 113-123.

Dainteath, M. \& Quin, B. (1991). Live feeds-low cost alternative. Austasia Aquaculture, 5, 19-22.

Gawlicka, A., Parent, B., Horn, M.H., Ross, N., Opstad, I., \& Torrisen, 0.J. (2000). Activity of digestive enzymes in yolk-sac larvae of Atlantic halibut (Hippoglossus hippoglossus): indication of readness for first feeding. Aquaculture, 184(3-4), 303-314.
Genodepa, J., Sothgate, P.C., \& Zeng, C. (2004). Preliminary assessment of a microbound diet as an Artemia replacement for mud crab, Scylla serrrata megalopa. Aquaculture, 236, 497-509.

Guillaume, J. (1997). Protein and amino acids. In Abramo, D., Conklin, L.R., \& Akiyama, D. (Eds.), Crustacean nutrition. The World Aquaculture Society, Advances in World Aquaculture, Baton Rouge, Lousiana.

Haryati. (2002). Responce of milkfih (Chanos chanos Forskall) larvae on the artificials diets in the hatchery system. Dissertation Graduate Program Bogor Agricultural University, $184 \mathrm{pp}$.

Haryati, Fujaya, Y., Saade, E., Zainuddin, \& Aslamiah. (2014). The development of the digestive enzymes activity of larval mud crab (Scylla olivacea) zoea to megalopa stages and its relationship with the ability to use artificial feed. Aquacultura Indonesiana, 15(1), 35-41.

Haryati, Fujaya, Y., \& Anugrah. (2015). The effect of the replacement of live foods with artificial diets on the digestive enzyme activity of mud crab (Scylla olivacea) larvae. Proceding of National Seminar of Fisheries and M arine Sciences XII, Gadjah Mada University, p. 137-144.

Holme, M.H., Zeng, C., \& Southgate, C. (2006). Use of microbound diets in the larviculture of the mud crab, Scylla serrata. Aquaculture, 257, 482-490.

Holme, M.H. (2008). Towards development of formulated diet for mud crab (Scylla serrata) larvae, with emphasis on lipid nutrition. PhD Thesis. James Cook University, $190 \mathrm{pp}$.

Jantrarotai, P., Srakaew, N., \& Sawanyatiputi, A. (2005). Histological study on the development of digestive system in zoeal stages of mud crab (Scylla olivacea). Kasetsart J. (Nat. Sci.), 39, 666-671. 
Mardjono, M., Anindiastuti, Hamid, N., Djunaidah, I.S., $\&$ Satyantani, W.H. (1994). Guidance seeding mud crab (Scylla serrata). Directorate General of Fisheries, Aquaculture Centres Brackish Water, Jepara, $40 \mathrm{pp}$.

Pavasovic, M., Richardson, N.A., Anderson, A.J., Mann, D., \& Mather, P.B. (2004). Effect of pH, temperature and diet on the digestive enzyme profiles in the mud crab, Scylla serrata. Aquaculture, 242, 641654.

Serrano, A.E. \& Traifalgar, R.F. (2012). Ontogeny and induction of digestive enzymes in Scylla serrata larvae fed live or artificial feed or their combination. AACL Bioflux, 5(3), 101-111.

Sheen, S.S. \& Wu, S.W. (1999). The effect of dietary lipid levels on the growth response of juvenile mud crab, Scylla serrata. Aquaculture, 93, 121-134.

Shelley, C. \& Lovatelli, A. (2011). Mud crab aquaculture (A practical manual). FAO Fisheries and Aquaculture Technical Paper (567), 100 pp.
Steel, R.G.D. \& Torrie, J.H. (1993). Principles and prosedure of statistics. Jakarta: PT Gramedia Pustaka Utama, 748 pp.

Suprayudi, M.A., Takeuchi, T., \& Hamasaki, K. (2004a). Essential fatty acids for larval mud crab, Scylla serrata: Implications of lack the ability to bioconvert $\mathrm{C} 18$ unsaturated fatty acids to highly unsaturated fatty acids. Aquaculture, 231, 403-416.

Suprayudi, M.A., Mursitorini, E., \& Jusadi, D. (2004b). Effect of Artemia sp. enrichment with EPA (Eicosapentaenoic acid, $C_{20}: 5 n-3$ ) and DHA (Docosahexaenoic acid, $\mathrm{C}_{22}: 6 \mathrm{n}-3$ ) on survival rate of swimming crab Portunus pelagicus. Aquaculture Indonesian Journal, 5(2)119-126.

Takeuchi, T. (2000). A review of studies on the effect n-3 highly unsaturated fatty acids on larval swimming crab Portunus triturberculatus and mud crab Scylla transquebarica. JSPS-DGHE International Symposium. 